\title{
9
}

\section{Unleashing the Power of Mechanization}

\author{
Xinshen Diao, Frances Cossar, Nazaire Houssou, \\ and Shashidhara Kolavalli
}

\subsection{Introduction}

As in most of Africa, agricultural mechanization in Ghana has been slow to develop, either in the form of animal or tractor power. But this has changed markedly since the early 2000s, and today about one third of all Ghana's farmers report using some form of mechanization, mostly tractors for land preparation, as do over half the farmers with five or more hectares of cropped land. However, policymakers often are skeptical of the role played by the private sector in providing mechanization services and worry that supplyside issues may be constraining its uptake, especially amongst smaller-sized farms. With this in mind, the government recently started to directly engage in the importation and subsidization of tractors, and has established a network of subsidized agricultural mechanization service centers around the country (Diao et al. 2014). The government program operates in direct competition with an already established private sector supply system, and this raises a number of important questions. In particular, is the government program overcoming some inherent market failure problems or is it introducing market distortions in machinery prices, encouraging rent-seeking behavior and possibly crowding out more efficient private suppliers? If the latter, then as suggested in Chapter 6, the program may be an unnecessary and costly addition to the financial burden of the public sector.

To address these issues, we review recent developments in the uptake of agricultural mechanization in Ghana, and of the factors that are driving the growth in farmers' demand. We then discuss possible supply-side constraints, and evaluate the government's recent interventions and their impact on the existing private sector alternative. This leads to our conclusions about appropriate mechanization policies for the future. 


\subsection{Mechanization Trends in Ghana}

Until recently, most cropped land in Ghana was cultivated manually, and use of animals or tractors for plowing was limited, despite early governmentsponsored mechanization programs in the 1960s. The use of animal traction has always been constrained by tsetse fly problems in much of the country, ${ }^{1}$ but recent years have seen rapid growth in demand for tractor plowing.

The agricultural census data are unreliable for showing trends in the ownership of tractors, but Figure 9.1 shows the substantial growth in the import of new and used tractors since 2003. Data on the use of mechanization is also available from the GLSS surveys and a recent Labor Force Survey conducted in 2015/16 (GSS 2016). The share of households incurring expenses for any type of agricultural mechanization (including purchasing or hiring machines and operating, maintenance, and repair costs) increased from virtually zero in 1991/2 to 17.5 percent in 2005/6, and then almost doubled to 32.5 percent in 2012/13. Mechanization is most prevalent in the Upper West and Northern regions and in the Greater Accra region, regions where 75 percent or more of farmers report spending on mechanization. The least mechanized regions are the Central and Ashanti regions, where less than 10 percent of farmers report spending on mechanization. One reason for this regional distribution is that the dominant

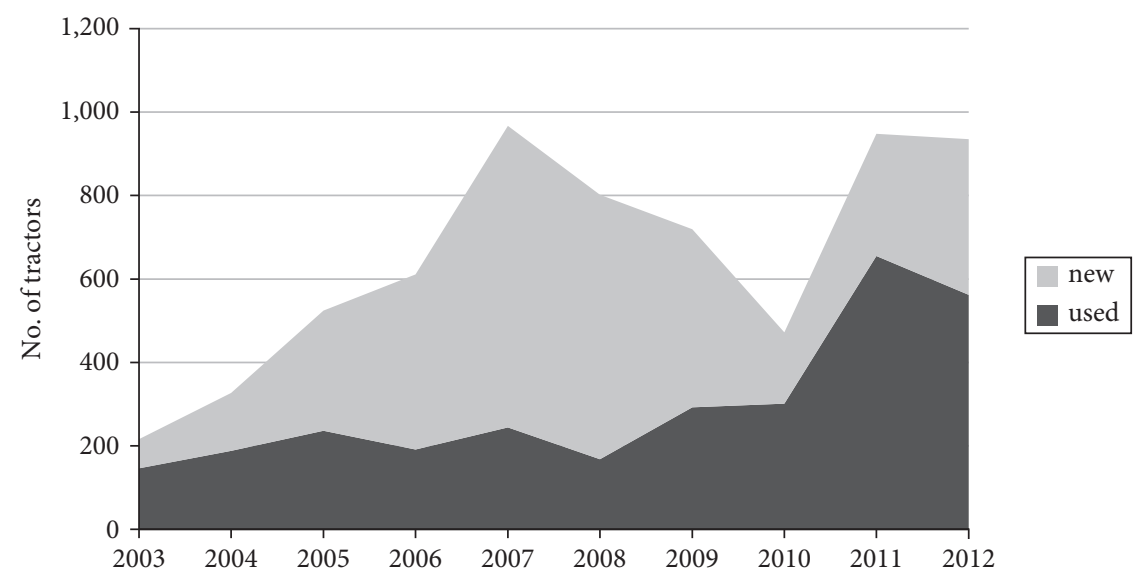

Figure 9.1. Tractor imports, 2003 to 2012

Note: Data for 2012 are to July 2012.

Source: Customs, Excise and Preventive Service, Government of Ghana.

${ }^{1}$ Draft animals are used more widely in the very north of the country where they are complementary with tractors (Houssou et al. 2013a). 
Table 9.1. Share of rural households using mechanization (percent)

\begin{tabular}{|c|c|c|c|c|c|}
\hline & \multicolumn{4}{|c|}{ Farm size } & \multirow[t]{2}{*}{ Total } \\
\hline & $<2$ ha & $2-5$ ha & 5-20 ha & $>20 \mathrm{ha}$ & \\
\hline $\begin{array}{l}\text { National: } \\
1991 / 2\end{array}$ & & & & & 1.0 \\
\hline $2005 / 6$ & 12.9 & 20.3 & 27.0 & 34.4 & 17.5 \\
\hline $2012 / 13$ & 22.0 & 37.8 & 53.6 & 72.8 & 32.5 \\
\hline $\begin{array}{l}\text { North: } \\
2005 / 6 \\
2012 / 13\end{array}$ & $\begin{array}{l}10.2 \\
22.2\end{array}$ & $\begin{array}{l}13.4 \\
37.9\end{array}$ & $\begin{array}{l}17.6 \\
56.3\end{array}$ & $\begin{array}{l}22.8 \\
76.4\end{array}$ & $\begin{array}{l}12.8 \\
35.9\end{array}$ \\
\hline $\begin{array}{l}\text { South: } \\
2005 / 6 \\
2012 / 13\end{array}$ & $\begin{array}{l}14.0 \\
21.9\end{array}$ & $\begin{array}{l}24.7 \\
37.7\end{array}$ & $\begin{array}{l}32.1 \\
51.3\end{array}$ & $\begin{array}{l}47.4 \\
67.2\end{array}$ & $\begin{array}{l}19.8 \\
30.8\end{array}$ \\
\hline
\end{tabular}

Note South $=$ Coastal + Forest zones; North $=$ Savannah + Transition zone . Source: Authors' calculations using GLSS3, GLSS5, and GLSS6.

form of mechanization is tractor plowing, and this is more relevant in regions that grow field crops than in the forest and cocoa growing areas.

Larger farms with more than five hectares are much more mechanized than smaller farms in both the North and the South (Table 9.1). While the largest farms often own their own tractors, most other farms are too small to justify such a lumpy investment and must hire in tractor services. Some medium-sized farms are able to justify purchasing a tractor by hiring out tractor services once they have met their own mechanization needs. A 2013 survey jointly conducted by IFPRI and the Savannah Agricultural Research Institute (SARI) in eight districts in the Northern and Central regions of Ghana found that more than 60 percent of the surveyed farmers used tractors for plowing, and that two thirds of them (who were all medium- and small- scale farmers) did not own a tractor but hired tractor services in (Diao et al. 2014). Of the medium- and large-scale farmers who owned tractors, 78 percent reported hiring out plowing services to other farmers during the survey year. Since the average farm size is larger in the Northern region and large farms are more likely to mechanize, then it can also be inferred that the share of the cropped area that is mechanized has also increased.

\subsection{The Emerging Demand for Agricultural Mechanization in Ghana}

Why has mechanization finally taken off in Ghana since the early 2000s? What has driven demand and to what extent has the supply of mechanization 
services kept up with potential demand? We explore the determinants of demand in this section, and then consider supply-side issues in Section 9.4.

A large literature exists that aims to explain the slow evolution of agricultural mechanization in Africa. One theory, developed by Hans Ruthenburg (1980) and based on his historical analysis of the evolution of tropical farming systems, predicts that farming communities will only adopt draft animals or tractors for land preparation once their land-use intensity reaches a critical threshold. Ruthenburg measured land-use intensity as the ratio of the harvested area to the total agricultural area (cropland plus fallow land) - which he called the $\mathrm{R}$ ratio, and concluded that this ratio needed to exceed 33 percent before mechanization of land preparation would take hold. This is equivalent to when the average fallow period has been shortened to less than two years for each year of cultivation. One reason for the switch in technology is that as fallows get shorter, grassy weeds and hardened soils become more serious problems and they are hard to overcome with hand hoeing, making animal or tractor plowing more attractive.

Diao et al. (2014) have calculated annual R-values for Ghana over the period 1961 to 2011 (Figure 9.2). Ghana was a relatively land-abundant country with low R-values until the late 1990s, during which time there was little evidence of rising demand for tractor mechanization. From the late 1990s onwards, however, the R-values have permanently risen above the threshold of 33, reaching 40 to 43 in the late 2000s. While this highly aggregated data fails to capture important regional variations, it does suggest that farming systems and land-use intensity have changed significantly in Ghana since the late 1990s, and which is consistent with the recent growth in demand for tractor plowing.

Ruthenburg's $\mathrm{R}$ ratio does not consider other economic factors that might affect mechanization besides land-use intensity, and these need to be taken

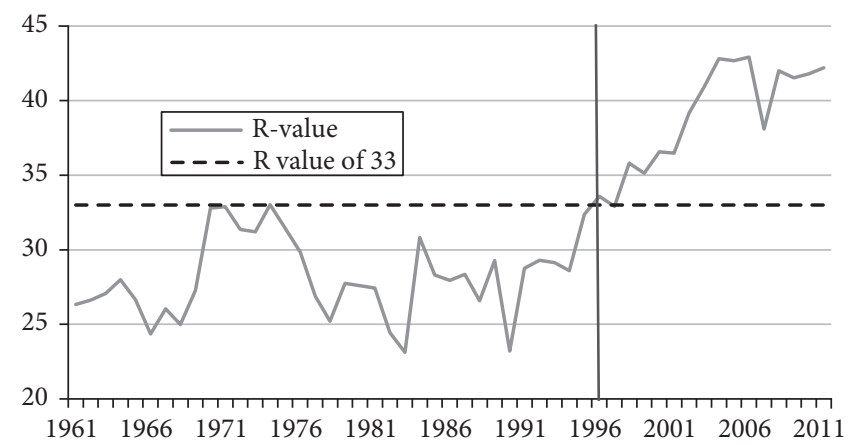

Figure 9.2. R-value measure of farming system evolution in Ghana, 1961-2011 Source: Compiled from FAO data. 
into account in explaining the recent growth of agricultural mechanization in Ghana. Another relevant theory from the literature is the induced innovation theory, which essentially predicts that since mechanization is a labor-saving technology, demand will develop once labor becomes sufficiently costly relative to capital and other purchased inputs (Hayami and Ruttan 1970, 1985; Binswanger and Ruttan 1978; Pingali et al. 1987). This typically happens after a country has reached a point in its economic transformation where the absolute number of workers remaining in agriculture begins to decline, and the land/labor ratio increases. For field crops, this usually leads to farms getting bigger, and with greater scarcity of labor relative to land, farmers have incentive to adopt labor-saving technologies like mechanization. However, as Chapter 5 shows, this change can be accelerated by rapid urbanization, which in addition to pulling workers out of agriculture, leads to more diversified rural livelihoods amongst remaining farm households, and hence to greater wage competition between agriculture and the nonagricultural sectors. Changes in urban diets may also lead to expansion of more labor-intensive crops, adding to the competition for labor.

We look at the evidence on three key drivers that may have led to induced innovation: changes in the land/labor ratio, changes in farm size, and changes in urbanization.

\subsubsection{Land/Labor Ratio}

Unlike many African countries, Ghana is still a relatively land-abundant country, and as shown in Table 9.2, the average cropped area per rural person actually increased by 11.8 percent between 2000 and 2010. This happened despite continued population growth because the rapid urbanization of the country has pulled many workers out of agriculture on a full- or part-time basis, while at the same time changing market opportunities have led farmers to increase their cultivated areas (see Chapters 4 and 6). However, there are important regional differences in these changes as shown in Table 9.2. Looking across regions, there is an inverse relationship between increases in the cropped area per rural person over 2000 to 2010 and population density. For example, the Brong Ahafo region experienced the largest percentage increase in its cropped area per rural person (52.5 percent) and it was also the region with the lowest population density in 2010. At the other extreme, the Greater Accra region experienced a 38.8 percent decline in its cropped area per rural worker, and had the highest population density in 2010. 
Table 9.2. Crop area per rural person, by region, 2000 and 2010

\begin{tabular}{|c|c|c|c|c|c|}
\hline \multirow[t]{2}{*}{ Region } & \multirow{2}{*}{$\begin{array}{l}2010 \text { Rural } \\
\text { population density } \\
\left(\text { persons } / \mathrm{km}^{2}\right)\end{array}$} & \multirow{2}{*}{$\begin{array}{l}2010 \text { share in national } \\
\text { food crop area } \\
\text { (percent) }\end{array}$} & \multicolumn{3}{|c|}{$\begin{array}{l}\text { Crop area per rural } \\
\text { person (ha) }\end{array}$} \\
\hline & & & 2000 & 2010 & $\begin{array}{l}\text { Percent } \\
\text { change }\end{array}$ \\
\hline Western & 57 & 6.7 & 0.20 & 0.18 & -6.7 \\
\hline Central & 118 & 7.0 & 0.20 & 0.23 & 12.3 \\
\hline Greater Accra & 117 & 0.3 & 0.06 & 0.03 & -38.8 \\
\hline Eastern & 77 & 14.1 & 0.34 & 0.35 & 4.0 \\
\hline Volta & 68 & 5.9 & 0.14 & 0.16 & 16.2 \\
\hline Ashanti & 77 & 12.8 & 0.24 & 0.26 & 7.7 \\
\hline Brong Ahafo & 32 & 18.5 & 0.35 & 0.54 & 52.5 \\
\hline Northern & 25 & 16.1 & 0.33 & 0.35 & 7.0 \\
\hline Upper West & 32 & 10.6 & 0.58 & 0.68 & 16.8 \\
\hline Upper East & 94 & 8.0 & 0.41 & 0.36 & -12.6 \\
\hline National & 51 & 100.0 & 0.28 & 0.31 & 11.8 \\
\hline
\end{tabular}

Source: Diao et al (2014).

The regions that experienced the largest increases in their land/labor ratios are also the most important regions in terms of national food-crop production (Table 9.2). Labor also became more expensive as real wage rates were pulled up by competition from rural nonfarm jobs, growing by nearly 7 percent per year on average over 1991 to 2012 at both national and regional levels (Chapter 4, Tables 4.9 and 4.10). As revealed in the village studies, these increases have been an important driver of changes in farming practices, including mechanization, in the agriculturally important savannah and transition zones (Chapter 6).

\subsubsection{Farm Size}

One consequence of an increasing land/labor ratio has been that farms have grown larger in size. Nationally, there has been an increase in the share of middle-sized (2-20 ha) farms at the expense of small ( $<2 \mathrm{ha}$ ) and large ( $>20 \mathrm{ha}$ ) farms, and medium-sized farms now account for half of all farms (Table 9.3). This change masks important differences at regional levels. In the Northern region (comprising the savannah and transition zones), medium-sized farms have forged ahead and now account for 60 percent of all farms, and this has been at the expense of small and large farms. However, there has been a reverse trend in the south (comprising the forest and coastal zones), where the share of medium-sized farms has actually declined (from 44.7 to 41.1 percent) and the 
Table 9.3. Changes in the farm size distribution, 2005/6 and 2012/13

\begin{tabular}{lccc}
\hline & Small $(<2$ ha $)$ & Medium $(\mathbf{2}-20$ ha $)$ & Large $(>20$ ha $)$ \\
\hline National: & & & \\
$2005 / 06$ & 53.3 & 44.7 & 1.9 \\
$2012 / 13$ & 49.3 & 49.8 & 0.9 \\
North: & & & \\
$2005 / 06$ & 44.3 & 52.5 & 3.2 \\
$2012 / 13$ & 38.6 & 60.0 & 1.4 \\
South: & & & \\
$2005 / 06$ & 53.3 & 44.7 & 1.9 \\
$2012 / 13$ & 58.4 & 41.1 & 0.5 \\
\hline
\end{tabular}

Note: South $=$ Coastal + Forest zones; North $=$ Savannah + Transition zone.

Source: Authors' calculations using GLSS5 and GLSS6.

share of small farms has increased. Since medium- and large-sized farms are the most likely to mechanize, then these trends suggest that mechanization is likely to have grown faster in the north than in the south of the country.

\subsubsection{Urbanization}

The impact of urbanization on mechanization is explored in detail in Chapter 5. A key finding is that while there is no consistent pattern of mechanization across levels of urbanization in the south, in the north the level of mechanization is significantly higher in the districts with larger cities than other districts, particularly among smallholders with less than two hectares.

Given the above patterns of change in land/labor ratios, farm size, and urbanization, the induced innovation theory leads us to infer that mechanization should: a) be more likely in northern Ghana where the land/labor ratio is highest and the share of small sized farms is lowest, b) increase with farm size, and c) increase with urbanization. These expectations are consistent with the actual patterns of adoption reported in Table 9.1, confirming that mechanization in Ghana is demand led and a response to evolving economic incentives. This conclusion is consistent with findings in Chapter 6 which show that farmers in the savannah and transition zones are increasing their cropped areas and adapting their farming practices, including mechanization, in response to higher local wages and better market opportunities.

Although mechanization has been demand led, there is still the question of whether the supply of mechanization services has kept pace with potential 
demand. Hard evidence on possible market failures is hard to come by, but as found in the farm modeling work in Chapter 6, the optimal share of the cropped area that should have been mechanized in 2010 is much higher than the actual that year. This suggests that supply is constraining the adoption of mechanization, although there could of course be other reasons why farmers are not optimizing in the way the model predicts. We end this section with some of our own observations from multiple field visits in Ghana during 2012-18 when we interviewed many different types of farmers, including tractor owners and renters, specialized tractor contractors, and smallholders. We heard many complaints from smallholder farmers who hire in about the difficulties of obtaining adequate tractor services for plowing and at the right times, and how they often had to approach several tractor owners before securing the plowing services they needed. However, we did not hear a single complaint from a tractor owner about there being insufficient demand for his/her services; in fact, most said they were inundated with more requests than they could handle during the plowing season.

\subsection{The Supply of Mechanization Services in Ghana}

Demand for mechanization need not always lead to an adequate supply response, particularly when such demand comes from many small- and medium-scale farmers and the industry is at an early stage of development. While many farmers might be willing to pay market prices for hired services, few have a sufficiently large farm to justify owning a tractor given the sizeable lump-sum cost involved. Governments in Africa, including Ghana, often use this as an argument to justify a subsidized mechanization program. However, while this might improve access for smaller farms, there is a risk that subsidized programs can distort market prices for agricultural machinery and discourage private investment, leading to market inefficiencies and long-term costs to the government, and impede the longer-term development of a vibrant private sector supply chain.

In Ghana, there are currently two parallel supply channels for agricultural mechanization services for farmers; a government-sponsored Agricultural Mechanization Services Center (AMSEC) program; and a private sector system of importers, machinery service providers (many of which are medium-scale farmers), and repair and maintenance shops. We consider each in Sections 9.4.1 and 9.4.2 that follow. 


\subsubsection{Ghana's Agricultural Mechanization Services Center (AMSEC) Program}

The government's current involvement in mechanization services through its AMSEC program is not a new phenomenon in Ghana. In the 1960s, the Ministry of Agriculture owned and operated an estimated 1,500 tractors in its thirty-two district mechanization stations in the savannah zone (Seager and Fieldson 1984). This program failed partly because of weak farmer demand for mechanization, but also because service charges for the provision of plowing services were set too low (about 50 percent of their real costs) making the program financially unsustainable for the government. From then until the early 2000s, the supply of mechanization was left largely to the private sector. However, since 2003 the Government started again to intervene in the market with its AMSEC program, on the grounds that small-scale farmers were not receiving adequate tractor services. The program operates with the government importing tractors and providing them on a subsidized basis to its machinery service centers.

\subsubsection{State-led tractor imports}

The main source of funding for AMSEC is through concessional loans received by the government from various emerging economies such as Brazil, China, and India. Such concessional loan agreements require that Ghana import tractors from the lender country. Therefore, different loan agreements have brought in different brands of tractors from different countries. In theory, the government does not directly handle the importation of any tractors, but uses private agents to act on its behalf. However, the government selects the private agents and they have no say over the type of machinery to be imported or to negotiate prices; these are determined as part of the loan agreements between the government and the donor countries. The import of Farmtrac tractors is a good example of the process and its problems. After receiving a concessional loan for tractor imports in 2007 and 2008 from the Export-Import Bank of India, the government selected a local company as its import agent. The company imported 500 Farmtrac tractors from India during 2007 and 2008, but had no say in the selection of the Farmtrac brand, the tractor models chosen, or the import prices. Expecting their business to continue with the government, the company constructed a large warehouse and built up stocks of spare parts with its own money. However, in 2009 the government entered into a new concessional loan arrangement with 
the Indian government for importing John Deere machinery manufactured in India, and a new local company was selected as the government's importing agent. This undercut the company importing Farmtrac tractors; not only could they no longer import subsidized tractors from India, but their own investment in building up a stock of spare parts was devalued. Similar onetime arrangements have been made recently for importing Mahindra tractors from India and other brands from China, Brazil, and other countries.

\subsubsection{Government-selected "private" entities as amsecs}

In order to avoid direct government management of mechanization services, private agents are selected by the government to own and operate the machinery services centers. The first group of seventeen AMSECs was established in 2007/8, a second group of fifty-two was established in 2009, and another twenty were established in 2010/11 (Diao et al. 2018). For the sixty-nine AMSECs established in 2007/9, each was given a package of five to seven tractors, with plows, harrows, and trailers, by the government. The cost of the tractors to the centers was subsidized by 30 percent, and the centers only had to pay 10-20 percent of the subsidized price as a down payment for a five-year interest-free loan. Given that the subsidized tractor prices are well below market prices to begin with, the generous financial arrangements seemingly make AMSECs a lucrative and attractive business, and the government has not had any difficulties in attracting applicants. In fact, there have been sufficient applicants and the government has had to turn many down, yet the criteria for selection is not known. This raises concerns about possible rent-seeking behavior.

\subsubsection{Difficulties with the amsecs program}

The AMSECs were designed to provide specialized tractor services to the local market without adequate consideration of whether this is profitable. Unfortunately, it turned out that many AMSECs were not profitable and have defaulted on their debt repayments, leaving the government responsible for the repayment of concessional loans. ${ }^{2}$

Houssou et al. (2013b) have demonstrated why tractor hiring alone is not profitable for many AMSECs. Based on subsidized tractor prices, actual operational costs in Ghana, and an assumed 10 percent capital depreciation

\footnotetext{
${ }^{2}$ According to a report published by Japan International Cooperation Agency (JICA) in 2015, the loan repayment rate for AMSECs established in 2007/8 was only 17.2 percent and 44.9 percent for those established in 2009. Almost one third of AMSECs have not made any repayment at all after the down payment (JICA 2015).
} 
rate, they calculate that a minimum of 287 hectares must be plowed per tractor each season in order for the net profit from plowing services to be comparable to the interest earnings from a similar-sized savings deposit in a bank account-a necessary condition for tractor renting to break even. Using survey data, Houssou et al. (2013b) also show that few AMSECs plow sufficient acreages to be profitable. An important reason is that the plowing season is too short to enable tractors to plow larger acreages within the localities that each AMSEC serves.

One way to increase the utilization of tractors is through seasonal migration to different regions with complementary plowing seasons. South Ghana, for example, has two cropping seasons while the North has one, and this difference could in theory be exploited by mobile tractor service providers to increase the number of operational days per tractor (Houssou et al. 2013b). In practice, there is little evidence of any of the AMSECs attempting to be regionally mobile, although there is evidence that some private tractor owners are doing so.

Another possible way to make AMSECs more profitable would be for them to diversify beyond plowing and offer a wider range of mechanization services. A survey by Benin et al. (2012) showed that in 2010, only thirty-eight machinery services firms among 136 surveyed provided services other than plowing, and even for such firms 80-90 percent of their revenue came from plowing. However, so far there has not been much demand for additional services in Ghana, and as experience in some other countries has shown, demand typically develops in parallel with innovation in the design and adaptation of other kinds of tractor implements and machines tailored to the niche needs of specific groups of farmers or localities (Diao et al. 2014). This kind of innovation is much more likely to arise in the private sector than with the government sponsored AMSECs.

\subsubsection{The Private Sector Alternative}

In addition to the heavily subsidized and state interventionist AMSEC program, there is a well-developed private sector supply chain of importers, machinery service contractors (mostly farmers), and repair and maintenance shops. Other than benefiting from an import tariff exemption that applies to all agricultural machinery imports, the private sector receives no other support from the government. The scale of the private sector alternative is significant; while the government imported about 3,000 new tractors and 300 power tillers 
over ten years, a similar, or even larger number of used tractors were imported by private importers in the same period (Ghana, CEPS 2012). The share of used tractors in total imports has increased substantially since 2010, and it is estimated that more than 10,000 tractors are currently operating in Ghana (Diao et al. 2018), suggesting considerable and growing demand for affordable tractors by the private sector.

Private importers are predominantly small-scale businessmen who have well-developed import channels, and tractors are typically only part of their business. This diversification enables then to spread their risks, and to smooth out the seasonal nature of the demand for tractors. Their clients are mostly medium- and larger-scale farmers, who find imported secondhand tractors much more affordable than new ones (USAID/ACDI-VOCA 2013).

Secondhand tractors are attractive to farmers not only because they are more affordable, but because they can obtain tractor brands of their own choice. Moreover, since the private sector has operated in the tractor import business for many years, the spare parts for the brands they import are available in most locations at reasonable prices. By contrast, the brands of new tractors imported by the government keep changing, and spare parts for them are harder to obtain.

Medium- and large-scale farmers are the main buyers of secondhand tractors from private importers, and they are also the main providers of mechanized services to other farmers. For most of them, hiring out tractor services after they have plowed their own land is an important way to justify the substantial lump-sum investment cost involved. On the other hand, as farmers they are not as dependent as the AMSECs on hiring out services for their income.

The 2013 IFPRI/SARI survey found that almost half of the small-scale farmers surveyed hired in tractor services for plowing, and these services were nearly all sourced locally, and mostly from other farmers (Benin et al. 2012). On average, tractor-owning farmers who hire out have 100-120 farmer clients, of which 45-51 are small-scale farmers with land less than two hectares. Because of the dominant role of medium- and large-scale farmers in providing tractor services, the market for land-preparation services is competitive. One outcome is that farmers in different locations are paying similar prices for plowing services, regardless of whether they hire in from private or AMSEC sources (Benin et al. 2012). 


\subsection{Conclusions}

Ghana's farming systems have undergone significant changes in the last thirty years and this has led to a growing demand for mechanization. So far, the demand has been primarily for tractor plowing, and this need is being met by parallel supply systems; the heavily subsidized and state interventionist AMSEC program, and a well-developed private sector supply chain of importers, machinery service contractors (mostly farmers), and repair and maintenance shops. Table 9.4 provides a summary of the key characteristics of the two supply systems.

The private system has developed without government support, and its lynchpin is a cadre of medium- and large-scale farmers who own used tractors and hire out tractor services to smaller-scale farmers when they are not

Table 9.4. Summary of Ghana's current supply models for agricultural mechanization

\begin{tabular}{|c|c|c|c|}
\hline & & AMSECs & The private sector \\
\hline \multirow[t]{4}{*}{$\begin{array}{l}\text { Service } \\
\text { provision }\end{array}$} & $\begin{array}{l}\text { Who owns } \\
\text { machinery }\end{array}$ & Nonfarm private enterprises & Medium and larger farmers \\
\hline & $\begin{array}{l}\text { Type of } \\
\text { machinery }\end{array}$ & New tractors $(50-80 \mathrm{hp})$ & $\begin{array}{l}\text { Used tractors and some } \\
\text { subsidized new tractors }\end{array}$ \\
\hline & $\begin{array}{l}\text { Type of } \\
\text { main } \\
\text { operation }\end{array}$ & $\begin{array}{l}\text { Hiring services: mainly } \\
\text { plowing }\end{array}$ & $\begin{array}{l}\text { Self-service and hiring } \\
\text { services: plowing, carting, } \\
\text { and maize shelling }\end{array}$ \\
\hline & $\begin{array}{l}\text { Scale of } \\
\text { operation }\end{array}$ & $5-7$ tractors & $1-2$ tractors \\
\hline $\begin{array}{l}\text { Machinery } \\
\text { supply }\end{array}$ & $\begin{array}{l}\text { Key } \\
\text { supplier }\end{array}$ & Government & $\begin{array}{l}\text { Private importers for used } \\
\text { machinery, and government } \\
\text { for new tractors }\end{array}$ \\
\hline $\begin{array}{l}\text { Supply of } \\
\text { attachments }\end{array}$ & $\begin{array}{l}\text { Market } \\
\text { players }\end{array}$ & $\begin{array}{l}\text { Government for imported } \\
\text { attachments and private } \\
\text { sector for imported spare } \\
\text { parts }\end{array}$ & $\begin{array}{l}\text { Private sector; some basic } \\
\text { implements manufactured } \\
\text { domestically }\end{array}$ \\
\hline $\begin{array}{l}\text { The key role } \\
\text { of the } \\
\text { government }\end{array}$ & $\begin{array}{l}\text { Policy } \\
\text { instruments }\end{array}$ & $\begin{array}{l}\text { Direct importation and } \\
\text { distribution of new } \\
\text { machinery; heavy price } \\
\text { subsidy and no interest } \\
\text { charge on outstanding } \\
\text { payment }\end{array}$ & $\begin{array}{l}\text { Duty-free imports of new } \\
\text { and used machinery; some } \\
\text { new tractors received from } \\
\text { MoFA at the subsidized } \\
\text { price }\end{array}$ \\
\hline $\begin{array}{l}\text { Source of } \\
\text { financing }\end{array}$ & & $\begin{array}{l}\text { Concessional loans from } \\
\text { foreign countries' } \\
\text { governments }\end{array}$ & $\begin{array}{l}\text { Cash transaction in used } \\
\text { machinery and no financial } \\
\text { support to the private } \\
\text { importers }\end{array}$ \\
\hline
\end{tabular}

Source: Authors' creation based on fieldwork interviews and review of policy documents. 
required for use on the home farm. These contractor farmers interface with private firms who import the tractors, and own machinery repair and maintenance shops, which also stock spare parts. This system is working well and has created a competitive market for hiring-in services. On the other hand, the AMSEC model recently promoted by the government seems not to be viable in its present form. Many of the AMSECs have unprofitable business models and struggle to pay their debts to the government, while the constant changing of imported tractor models and a lack of spare parts undermines the demand for the subsidized tractors that the government procures through its agents.

Continuation of the AMSEC program in its present form will only add to the financial burden on the government, diminish the role of the private sector in further developing the mechanization supply chain, and lead to rentseeking behavior amongst government selected agents who import tractors or run the AMSECs.

So far, the demand for mechanization in Ghana has not evolved much beyond tractors for land preparation and for shelling maize after harvesting. As wages continue to rise and farms get larger, additional demands for mechanizing other aspects of crop production, harvesting, transportation, water pumping, post-harvest processing and the like, will inevitable grow. Meeting this demand will require a flexible supply chain, one which can develop and/or adapt a variety of machinery types and services to meet a diverse set of farmer needs that will vary by type of farm and locality. Experience in several Asian countries, where farm mechanization for small-scale farms is much more advanced than in Ghana, shows that only the private sector has the capability to develop these kinds of flexible supply chains, and that heavy-handed government interventions can be counterproductive (Diao et al. 2014).

That said, there are things the government can do to support these developments. For example, the government could do more through field demonstration and perhaps some directed credit subsidies to promote the value of yieldenhancing mechanization practices like second-plowing and harrowing, and the adaptation and uptake of smaller tractors. The government might also usefully support appropriate mechanization research and technical training of young mechanics (Diao et al. 2018). However, a key question is whether the government will be willing to recognize the dominant role played by the private sector, and especially the renting-out services provided by medium- and largescale farmers, and rethink its AMSEC program. An effective mechanization policy should aim to strengthen the entire value chain for mechanization services and not just be limited to targeting specific types of services or providers. 


\section{References}

Benin, S., M. Johnson, K. Jimah, J. Taabazuing, A. Tenga, E. Abokyi, and G. Nasser. 2012. "Evaluation of Four Special Initiatives of the Ministry of Food and Agriculture, Government of Ghana." Draft Report, International Food Policy Research Institute, Washington, DC.

Binswanger, Hans and Vernon Ruttan. 1978. Induced Innovation. Baltimore: The Johns Hopkins University Press.

Boserup, E. 1965. The Conditions of Agricultural Growth: The Economics of Agrarian Change under Population Pressure. London: George Allen and Unwin.

Diao, X., F. Cossar, N. Houssou, and S. Kolavalli. 2014. "Mechanization in Ghana: Emerging Demand, and the Search for Alternative Supply Models." Food Policy 48(2014): 168-81.

Diao, X., J. Agandin, P. Fang, S. E. Justice, D. Kufoalor, and H. Takeshima. 2018. "Agricultural Mechanization in Ghana: Insights from a Recent Field Study." IFPRI Discussion Paper 10729, International Food Policy Research Institute, Washington DC.

Ghana, CEPS (Customs, Excise and Preventive Services). 2012. Import Data.

GSS (Ghana Statistical Service). 2016. 2015. “Labor Force Survey Report.” December 2016.

Hayami, Y., and V. W. Ruttan. 1985. Agricultural Development: An International Perspective. Baltimore: Johns Hopkins University Press.

Hayami, Y., and V. W. Ruttan. 1970. "Factor Prices and Technical Change in Agricultural Development: The United States and Japan, 1880-1960.” Journal of Political Economy 78(5): 1115-41.

Houssou, N, S. Kolavalli, E. Bobobee, and V. Owusu. 2013a. “Animal Traction in Ghana." Ghana Strategy Support Program Working Paper No. 34. Washington, DC: International Food Policy Research Institute.

Houssou, N., X. Diao, F. Cossar, S. Kolavalli, K. Jimah, and P. Aboagye. 2013b. "Agricultural Mechanization in Ghana: Is Specialization in Agricultural Mechanization a Viable Business Model?" American Journal of Agricultural Economics 95(5): 1237-44; doi: 10.1093/ajae/aat026.

JICA (Japan International Cooperation Agency). 2015. “Expert on Smallholder Farmers' Access to Agriculture Mechanization in Ghana-Project Completion Report." Tokyo.

Pingali, P., Y. Bigot, and H. Binswanger. 1987. Agricultural Mechanization and the Evolution of Farming Systems in Sub-Saharan Africa. Washington, DC: World Bank.

Ruthenburg, H. 1980. Farming Systems in the Tropics. Oxford: Oxford University Press. 
Seager, P. J., and R. S. Fieldson. 1984. "Public Sector: Tractor Hire and Equipment Hire Schemes in Developing Countries." Paper Prepared by the Overseas Division of NIAE.

USAID/ACDI-VOCA. 2013. "ADVANCE Tractor Census of Northern Ghana." Washington, DC. 